\title{
Teaching-service integration: implications and roles in experiences of Undergraduate Courses in Nursing*
}

\author{
INTEGRAÇÃO ENSINO-SERVIÇO: IMPLICAÇÕES E PAPÉIS EM VIVÊNCIAS DE \\ CURSOS DE GRADUAÇÃO EM ENFERMAGEM
}

\author{
INTEGRACIÓN ENSEÑANZA-SERVICIO: IMPLICANCIAS Y ROLES EN LAS \\ EXPERIENCIAS DE CURSOS DE PREGRADO EN ENFERMERÍA
}

\author{
Laura Cavalcanti de Farias Brehmer', Flávia Regina Souza Ramos²
}

\begin{abstract}
The study aimed at understanding the implications of the teaching-service integration to nursing education from the perspective of teachers, students and professionals in Primary Healthcare as well as identifying the roles of teachers and professionals who follow practical experiences in education. This is a case study of qualitative approach carried out in five undergraduate courses in Nursing in the state of Santa Catarina. A total of 22 teachers and 14 professionals were interviewed and five focus groups were conducted with students. Results are presented in two categories: Implications of the teaching-service integration to education in Nursing: contributing factors and intervening factors and Relationships established in the experiences: a unison speech and a dissonant practice. The contributions of the teaching-service integration are undeniable. Despite this belief, there are intervening factors that need to be on the agenda for discussion. The role of facilitator in education emerged strongly despite conflicting perceptions remain.
\end{abstract}

\section{DESCRIPTORS}

Education nursing

Education higher

Teaching Care Integration Services

\section{RESUMO}

O estudo buscou conhecer as implicações da integração ensino-serviço para a formação em Enfermagem na perspectiva de docentes, alunos e profissionais dos serviços de Atenção Básica à saúde e identificar os papéis de docentes e profissionais que acompanham as vivências práticas na formação. Pesquisa qualitativa, do tipo estudo de caso, desenvolvida em cinco cursos de graduação em Enfermagem do estado de Santa Catarina. Foram entrevistados 22 docentes e 14 profissionais e realizados cinco grupos focais com alunos. Os resultados são apresentados em duas categorias: As implicações da integração ensino-serviço para a formação em Enfermagem: fatores contributivos e intervenientes e Relações que se estabelecem nas vivências: um discurso uníssono e uma prática dissonante. As contribuições da integração ensino-serviço são inegáveis. Apesar dessa convicção, existem fatores intervenientes que precisam estar na pauta das discussões. O papel do facilitador na formação também emergiu de modo veemente, embora persistam percepções contraditórias.

\section{DESCRITORES}

Educação em enfermagem

Educação superior

Serviços de Integração Docente-Assistencial

\section{RESUMEN}

El objetivo de este estudio fue conocer las implicancias de la integración enseñanzaservicio, para la formación en enfermería desde la perspectiva de docentes, alumnos y profesionales de los servicios de atención primaria de salud, además de identificar las funciones de los actores que participan en el proceso de formación durante las experiencias prácticas. Se trata de una investigación cualitativa, tipo estudio de caso, realizada en cinco cursos de pregrado en enfermería en el estado de Santa Catarina. Se entrevistaron veintidós docentes y catorce profesionales y se realizaron cinco grupos focales con los alumnos. Los resultados son presentados en dos categorías: Las implicancias de la integración enseñanza-servicio para la formación en enfermería, factores contribuyentes e intervinientes y Relaciones que se establecen en las vivencias, un discurso unísono y una práctica disonante. Las contribuciones de estas experiencias son innegables, sin embargo existen factores intervinientes que requieren estar en la pauta de las discusiones. El rol del facilitador en la formación emergió fuertemente a pesar de la persistencia de percepciones contradictorias.

\section{DESCRIPTORES}

Educación en enfermería

Educación superior

Servicios de Integración Docente Asistencial

\footnotetext{
*Extracted from the thesis "A integração ensino-serviço em experiências do Pró-Saúde na Enfermagem/SC: estratégia para a consolidação da Atenção Básica à Saúde". Post-Graduate Program of Nursing at the Federal University of Santa Catarina (UFSC), Brazil, 2013. ${ }^{1}$ Nurse, PhD in Nursing. laurinhacf@gmail.com ${ }^{2}$ Nurse, PhD in Nursing, Associate Professor in the Department of Nursing and the Post-graduate Program at the Federal University of Santa Catarina (UFSC), Brazil. flaviar@ccs.ufsc.br
} 


\section{INTRODUCTION}

The teaching-service integration comprises the collective, agreed and integrated working process between education and health managers and among teachers, students and employees in healthcare. It is a strategy of the training process, but its goals are expanded as they turn to the quality of care in health ${ }^{(1)}$.

For many years the Higher Education Institutions - HEI and health services have created instruments of cooperation, partnerships or agreements to perform teaching practices at sites of healthcare. In 1981 it was created the Teaching-Care Integration Program (PIDA - Programa de Integração Docente-Assistencial), a national program aimed at not limiting the teaching-service integration to the use of health facilities for the practice of teaching ${ }^{(2)}$. This program is just one example of the institutionalization of teaching-service strategies of integration. As this initiative, many others have emerged and exist until today to promote experiences based on guidelines for promoting the integration of students in real contexts of work in health in a more consolidated way.

One of the competencies of Brazil's Unified Health System (SUS - Sistema Único de Saúde) is the regulation for developing human resources for health, according to the Organic Health Law 8.080/1990. Changes are urgent in the process of education in order to suit the professional profile to the principles and demands of the system. The whole strategy of strengthening the experiences of teaching-service integration represents an expansion of the potentialities in a much larger process, which is the consolidation of SUS.

The integration between $\mathrm{HEI}$ and SUS services requires actions based on horizontal relations and joint working processes. The agreements should consider interests, needs and strengths, as well as recognizing and dealing with the heterogeneity of each part to constitute an agenda of common interests ${ }^{(3)}$.

Forums of dialogue between education and work in health have a privileged place in the development of students' perception about their career choices. These are spaces of citizenship in which individuals, with their knowledge and particular views of the world build and play their roles in society. The attention focused on the formation - beginning from the work process - is structured on inquiring about the actual and current elements that arise in the performance of daily tasks of the profession. The main objective is the transformation of professional practices $^{(1)}$.

Influenced by the processes of change in the areas of education and health, this work process requires consistency between the proposals of the academy and services in its political, technical and methodological dimensions. Institutionally made require collective accountability as they will not be effective and consolidated if they occur in the form of isolated initiatives ${ }^{(4)}$.

The dialogue between education and healthcare is able to mutually offer numerous possibilities of knowledge, action and especially integration. However, in order for these ideas to become effective, it is necessary to invest in the creation of spaces for dialogue between $\mathrm{HEI}$, the service and the community, to strengthen the role of each of them in a new guidance for education and in the reorganization of healthcare ${ }^{(4-5)}$.

This study aimed at a complex reference of construction of relationships and the consequences of implementing strategies of teaching-service integration in health education. It sought to understand the implications of the teaching-service integration in the nursing education from the perspective of teachers, students and professionals of health services and to identify the roles of teachers and professionals that accompany practical experiences in training.

The practical-theoretical experiences throughout education and especially the experiences in exterior scenarios print perceptions about the whole universe where the job is included. These experiences are perceptions about the work itself, about social aspects, the history and politics that interfere in the way professions are built, play their role and establish relationships.

Investigations with this focus may contribute to bring elements for reflection and discussion throughout the movement for change, implementation of strategies for professional training and quality of health services.

\section{METHOD}

The Multiple Case Study of qualitative approach was chosen to guide the development of this research. This study design is often used in descriptive and exploratory studies that seek to deeply understand a complex social phenomenon in its real context ${ }^{(6)}$.It included five graduate courses in Nursing of five HEl of the state of Santa Catarina.

Data collection was done through interviews based on a semi-structured script with 22 teachers and 14 professionals in Primary Care services. In each of the five cases, a focus group with students from the last period of the course (graduates of the first semester of 2011) was also carried out. The sample of teachers and service professionals was non probabilistic. The distribution of subjects by $\mathrm{HEl}$ varied but had a minimum of three faculty representatives and two service representatives in each case.

Interviews and focus groups were fully recorded and transcribed. The ATLAS-ti - The Qualitative Data Analysis Software was used to organize and categorize data.

In Case Studies, the analysis occurs simultaneously with data collection and was guided by the processes of Data Encoding to describe relevant concepts capable of 
meeting the goals, and by the Establishment of Analytical Categories, where concepts are grouped by similarity and for which are assigned theoretical meanings ${ }^{(7)}$.

The project was approved by the Committee of Ethics and Research with Human Beings of the Education Institute under number 1801/2011. In order to ensure anonymity of subjects and preserve the identification of cases, some specific codes were adopted, namely: Focus Group - FG1 to FG5; Teachers - T1 to T22 and Service Professionals - SP1 to SP14.

\section{RESULTS}

The outlined objectives guided the presentation of results by composing two general categories: 1 . Implications of the teaching-service integration to education in Nursing: contributing factors and intervening factors and 2. Relationships established in the experiences: a unison speech and a dissonant practice. These general categories were established from the nuclei of key concepts identified in the reports of the subjects of research.

\section{Implications of the teaching-service integration to education in Nursing: contributing factors and intervening factors}

The perceptions of students, teachers and healthcare professionals who experienced the teaching-service integration in Primary Care converged to a fundamental contribution, which is the ability to experience care and work in health during education. This finding may seem obvious, since that is the purpose of the strategy: to provide students with experiences that approach both these worlds - of care and work - during the training process. It indicates that the experiences of integrating teaching and service are reaching its goals accordingly.

However, there are two dimensions that go beyond this truism because they transcend the aspect of understanding teaching-service integration to put into practice the theory learnt in the classroom. Such dimensions are the articulation between theory and practice and the contextualized experiences according to the actual needs of health services.

The mechanical reproduction of theory into practice - an aspiration for some subjects and an expectation for others - is increasingly obsolete in the perception of those involved in education. In the consolidation of the teaching model there is no more room for this sterile way of planning and developing practices.

The fact that we are inside the health units since the first stage is already an amazing thing. You're already acclimated, you know how it works, you know what it is (FG 5).

Students have an ability to perceive that their world is not only what's in the classroom. Then they begin to realize that those attitudes, those discussions that they have in practice, where they are, begin to have a slightly greater impact (T 22).
I think from the moment you start to put academia in the same working environment, living with the unit, with professionals, I think the baggage of knowledge is quite great (SP 7).

Another aspect concerns the organization adopted by courses to meet the National Curriculum Guidelines (DCN Diretrizes Curriculares Nacionais), which guides to a training focused on health needs and the real demands of the health system. The academic goals have been planned together with health services, shortening distances between the academy proposals, health needs and processes of work in health.

This way of developing practices stands out to the eyes of students, teachers and professionals because it acquires meaning in everyday routine of services. These actions are not disconnected from reality and implemented only to meet curriculum requirements. In this sense, the development of socio-epidemiological research such as territorialization, smart maps used in the situation room as well as situational diagnostics and planning got stronger to subsidize contextualized practices.

The commitment of education in health should not be made only with the learning of students, but also to the resolution of health services and, consequently, with the population.

With prevention we did mainly the part of education in health at school ... This was a concern that came from the school to us, in that case the nurse wanted to bond with the school and this was the way to create that bond... (FG 2).

The logic of training cannot come from the teacher's head, it has to take into account the reality of the service, this has been widely considered (T 5).

They don't come with a planning. Of course the discipline more or less directs. First they ask what the service needs. It is quite focused on the needs (SP 6).

Contrary to the contributions, the subjects have considered about some factors that persist in limiting the progress of the teaching-service integration to education in health. In this respect, the consensus was guided by the intersection between academic organization and services organization. These limits are imposed by the organizational structure of the courses, resulting from the curricular grid, academic calendar and schedule availability, together with the working process dynamics of health teams that comprise services.

The university also has things that could be better... the subjects should be [given] in two semesters, because it was in such a rush, with little time to study (FG 1).

I think the limitations are still the organizational capacity of institutions, there is the issue of schedule, the way internships are conducted ... Because there is a routine in the unit, then there is no continuity ( $\mathrm{T} 17)$.

He recognizes the territory but as he comes [to the unit] only in three periods and he has so many activities, he is concerned about consultations and the assistance, he hasn't got much of this look of the whole (SP 1).
Teaching-service integration: implications and roles in experiences of Undergraduate Courses in Nursing Brehmer LCF, Ramos FRS 


\section{Relationships established in the experiences: a unison speech and a dissonant practice}

When the experiences of students in academic formation occur in health services, the role of the facilitator stands out and is specifically attributed to teachers and professionals of health teams. This fact permeated the reports and was present on the perception of subjects on how actions are taken in this strategy of the education process. In their roles as facilitators and in a sense beyond semantic, teachers and health professionals are committed with creating opportunities of experiences and learning.

It was not possible to find another role because this one seems to encompass everything that is expected from the work of these professionals and all that they perform in their jobs. Facilitator was a recurring name in the reports, a slogan strongly rooted in the speeches of all.

This conception of the role of teachers is recent, as well as the recognition of the role exerted in education by professionals that accompany practical experiences of students. It is a proposal of a horizontal relationship opposed to the vertical position of knowledge transmission.

Because we really felt like part of the education process, we weren't only students, we participated (FG 4).

The proposal is to work with the issue of questioning, to promote an exchange... The teacher is usually the facilitator, the mediator of this process ( $\mathrm{T} 16$ ).

Using a term, I believe it's facilitator, you often provide guidance because academics come without this experience (SP 6).

In contrast to these speeches, strong criticism emerged from students regarding the role of teachers and health services professionals, and from those same subjects who see themselves as facilitators of the training process in relation to their peers. Students question the faculty's commitment and, along with the other subjects of the study, realize how frail is the understanding of what it really represents and how the teaching-service integration happens in practice.

Important aspects of a process under construction appeared, with frail points in the ambit of interpersonal relationships and that represent a critical node for the consolidation of the integration strategy. Resistance and indifference were showed by some teachers and health professionals, the latter for considering the monitoring of students as an overload added to their work demands. There is still competition for physical space in health facilities to carry out the activities of teachers and students, and conflicting priorities between the typically academic actions and the routine of health services.

It is precisely in this context that the practices become effective, the action of subjects who are co-responsible for advances, stagnation or retrogression of the teaching-service integration, as well as of the training in health, in line with principles such as integrity, interdisciplinarity and quality of care.

I felt a lot of resistance from nursing technicians with us, lots of ... Same with doctors, many see us as just another one ... Others are cool, though ... They are either nice and hug you or they don't care for you (FG 2).

Professionals have this very logic that it's an extra service for them; it is not something that is part of the work process (T 9).

Many professionals, when students see, they block many things and even the teacher ... We observe that they could contribute better, sometimes it is very limited (SP 5).

No kind of reflection was identified in relation to the attitude of students towards their commitment to learning with the institutions and with the social. This may denote the centrality of the roles of teachers and professionals as agents and responsible for the teaching and learning process and the absence of a more critical awareness of students about their own roles. The development of a participatory teaching and learning process assumes coresponsibility and active participation of all the involved.

\section{DISCUSSION}

In the process of education in health, experiences of care and work in real settings of health certainly represent possibilities of articulation between the theoretical learning and the practice.

In the health area, from the National Curriculum Guidelines, the training oriented to the Unified Health System (SUS - Sistema Único de Saúde) favors the analysis of specific aspects of the system and of healthcare in this context. Thus there is the promotion of criticism and reflection about which elements represent advances and which require adjustments to consolidate the goal-images to be reached with public health policies.

In nearly two decades since the regulation of SUS, the health situation in Brazil showed significant changes, but its procedural and dynamic aspects indicate a path under constant construction. The teaching-service integration is an important strategy to tune the interests and objectives of the academy with the expectation of the System in order to promote the alignment of future health professionals and teachers with professionals who actually provide healthcare in the routine of service ${ }^{(8-9)}$.

When confronted with reality, teachers and students create opportunities to problematize it in order to define needs and prioritize the learning objects ${ }^{(10)}$. The intervention in the social dynamics awakens to the logic of strategically planning work. This attitude represents a challenge to teaching and students' understanding about education from the critical-reflective approach ${ }^{(11)}$. 
The social reality is determinant of the health status of a population and it is where health services are based. This understanding allows students to have a learning that is coherent with the concrete needs of people and the System. This awakening begins in the academy, increasing the chances of future health professionals guiding their practice under this logic in the end of their education ${ }^{(12)}$.

Although this understanding is increasingly present in the perception of all involved in this movement, there is a tenuous threshold between the standard of theoretical-practical integration into real life experiences of health services and the risk of mechanically reproducing inert speeches.

Education in Nursing and in other health professions undoubtedly is moving towards providing answers to the health needs and the real demands of the population. Curricula returned to favor the profile of a professional who is active and engaged to the scope of the public health system, especially with the resolution of individual and collective problems permeating the whole training process. The integration of education and health services from the beginning of the course aggregates effective elements to overcome the traditional fragmentation between theoretical learning and practical experience ${ }^{(13)}$.

In order to do so, an education nearer to Primary Healthcare is expected, as an opposition to the hegemony of hospital care which is deeply rooted in the conceptions of the individuals in the process. Despite the obstacles and complexity in providing a new guidance to education and healthcare, the undergraduate courses in the area have been showing alignment with these proposals and curricula, with educational policy plans, and actions that are being designed and developed from this point of view ${ }^{(14-15)}$.

Much is also expected from the organization of services in relation to its commitment to take responsibility for professional training, as established by the Federal Constitution of 1988. However, both the $\mathrm{HEI}$ and the services have a frail commitment. As shown in the results of this study, the academic organization and the service organization do not completely prioritize all the necessary elements in their organization for an education that is effectively integrated with the Health System.

There is a search for greater institutional awareness and, apart from the moments of reflection and evaluation present in practice, the involvement of all is necessary to fill the gaps, beginning from the planning of curricular activities until the bilateral pact of objectives of practices ${ }^{(16)}$.

The data presented in this study showed gaps, especially with the timetable distribution of general and specific Nursing disciplines and in the development of skills in the experiences of services. All seem concerned with detecting relative weakness in the corpus of knowledge built during the course and also with relative uncertainty regarding the actual link between this knowledge and practical experiences $^{(17)}$.

Integrating students' practices with the service routines is a constant challenge, because it directly depends on factors such as routines of the health units, class timetables and curriculum organization. In addition, there are structural factors of services such as organizing the ever growing demand which hinders the participation of health team professionals in training activities. It is also related with the conceptual bases and with the understanding of professionals with respect to the multi professional and interdisciplinary work ${ }^{(18)}$.

The difficulties of teaching-service integration are related to the incipient participation of service management in the construction of curricula, planning and development of practices. The intentions of the academia and the healthcare network do not converge and the objectives are not entirely common. While this reality persists, integration will remain a practice with many biases, despite the advances ${ }^{(19)}$

Another aspect investigated and demonstrated regards the relations established in the experiences of teaching-service integration. Students, teachers and health service professionals, when invited to think about the highlight roles of the case, all agreed in mentioning the role of facilitator.

The teacher or the facilitator teacher motivates and guides the learning of students, creates collaborative spaces and shares responsibilities. With this attitude the teacher encourages the manifestation of creativity and critical thinking of students. The learning objectives and the actions are discussed and defined together, under faculty guidance and with the active participation of students ${ }^{(20)}$.

Amid the movement for changes in education and health and the inducing action of the Ministries of Education and Health, the necessity to encourage the development of students' awareness to learn throughout life became a consensus. To this end, teachers and others involved with education need to be engaged in the proposal and offer learning based on exchange of information and knowledge. $\mathrm{HEI}$ and more specifically those responsible for thinking and designing courses in the area of health are investing in the provision of conditions for a teaching practice with the didactic-pedagogic profile of facilitator ${ }^{(21-22)}$.

Facilitator teachers, according to the perception of students, present themselves as warm reference people, of technical-scientific knowledge and knowledge related to solidarity ${ }^{(23)}$. The facilitator attitude is consistent with the methodology of questioning, however they face incomprehension from teachers and students regarding the conduction of the teaching and learning process. Students may feel helpless when facing decisions, due to never having experienced such autonomy throughout education years. The teacher can be seen as negligent or as a friend, biased perceptions of the guide and motivator roles ${ }^{(24)}$.
Teaching-service integration: implications and roles in experiences of Undergraduate Courses in Nursing Brehmer LCF, Ramos FRS 
There are experiences that showed the limiting aspects for understanding the facilitator role of teachers, and health professionals. Thus, the continuing education is imperative so that there are constant spaces of reflection on the pedagogical action, in order that the training of new professionals is actually grounded in an emancipatory construction of knowledge and practices, focused on students, on the health needs of the population and the Unified Health System (SUS) ${ }^{(25)}$.

The discussions about the roles of teachers and health service professionals need to be enhanced in order to consolidate, especially the joint responsibility of teaching and service in health education. The sensitization of subjects to these commitments requires constant exercises, as well as investment in engagement strategies for thinking and acting in education, in health and the interface between these areas $^{(16,26)}$.

However, there is another individual forgotten by the results of this research, but essential to the real meaning of the participatory teaching-learning process: the student. It is necessary to be aware of the commitment that students make in their professional training. Bringing students' participation to the construction of knowledge and conduction of their education careers is enforcing the assumptions of critical-reflective teaching.

All the elements that involve the processes of changes in education are not neutral, but permeated by struggles between positions and interests. This also involves a process of preparation of those responsible for implementing these changes, in the first instance the teachers and professionals who work in healthcare ${ }^{(27)}$. Therefore, discrepancies are still observed between the discourse introduced by theory and the everyday practice that is bounded by adverse conditions to the required transformations.

\section{CONCLUSION}

Thinking about teaching-service integration for health education is to think about making available a learning that is close to the reality of people's health and the Unified Health System and that meets the specific needs of both. One can also think of the possibility of exceeding the limits of the theory to environments exterior to universities, classrooms and laboratories. The practice

\section{REFERENCES}

1. Albuquerque VS, Gomes AP, Rezende CHA, Sampaio MX, Dias OV, Lugarinho RM. A integração ensino-serviço no contexto dos processos de mudanças na formação superior dos profissionais da saúde. Rev Bras Educ Med. 2008;32(3):356-62.

2. Brasil. Ministério da Educação e Cultura; Secretaria do Ensino Superior. Programa de Integração Docente-Assistencial - IDA. Brasília; 1981. experiences in care and work settings are a potential strategy for a contextualized training that is articulated with political and partnership demands.

The contributions of experiences of teaching-service integration are indisputable and undeniable. Data from this study confirmed the reflections of the exercise of practice-theory relation and the awakening of the critical and reflective awareness as the result of an education articulated with social dynamics, the reality of the profession and services and the attention to the needs of this interaction.

Despite this belief, there are intervening factors in experiences of teaching-service integration that need to be on the agenda of discussion since they represent limits to the advancement of the strategy. Organizational aspects of the course and the routine of health institutions that negatively interfere in the strengthening of experiences emerged from the perspective of students, teachers and professionals of health services.

Another aspect revealed in the study arises from the relationships established between individuals involved in the process. In these interactions all subjects outlined the key role of the facilitator. This figure attributed to the action of teachers and service professionals corresponds to the role of guidance, motivation and collective construction of learning with the integration of knowledge.

Two issues deserve attention in the analysis of empirical data. The first is how the discourse about the characteristics of the facilitator role in the formation is present in the speeches and the second is the contradiction of this discourse that is often evidenced in experiences.

In health education the legacies of vertical and authoritative teaching still persist, while in healthcare the principles of the biomedical model remain hegemonic. In this complex process of transformation the critical and reflective model of teaching-learning exists in parallel with the healthcare model that is in line with the organization and principles of the SUS - maybe not so new, but also not consolidated.

Strategies such as continuing education and a constant inter and intra-institutional dialogue can establish shared goals and gather interests aimed at promoting and strengthening the change process of education in health.

3. Feuerwerker LCM. Gestão dos processos de mudanças na graduação em medicina. In: Marins JJN, Rego S, Lampert JP, organizadores. Educação médica em transformação: instrumentos para a construção de novas realidades. São Paulo: Hucitec; 2004. p. 17-39.

4. Pereira JG, Fracolli LA. The contribution of the teaching-service integration to the implementation of the health surveillance model: educators' perspective. Rev Latino Am Enferm. 2009;17(2):167-73. 
5. Ceccim RB, Feuerwerker LCM. Mudanças na graduação das profissões de saúde sob o eixo da integralidade. Cad Saúde Pública. 2004;20(5):1400-10.

6. Yin RK. Estudo de caso: planejamento e métodos. 4a ed. Porto Alegre: Bookmann; 2010.

7. Gil AC. Como elaborar projetos de pesquisa. 5a ed. São Paulo: Atlas; 2010.

8. Lemos $M$, Rocha MND, Peixoto MVS. Estágio de vivência no SUS-BA: estratégia de reorientação da formação profissional em saúde. Rev Baiana Saúde Pública. 2012; 36(1):263-9.

9. Miechuanski PC, Kleba ME. Acadêmicos da Unochapecó na interação com Sistema Único de Saúde e ESF através do Projeto PRÓ-SAÚDE. Rev Bras Educ Med. 2012; 36(1 Supl 2):131-5.

10. Marin MJS, Caputo VG, Ishida E, Giovanetti JN, Pinto RT. Aprendendo com a prática: experiência de estudantes da Famema. Rev Bras Educ Med. 2007;31(1):90-6.

11. Vendruscolo C, Kleba ME, Krauzer IM, Hillesheim A. Planejamento situacional na Estratégia Saúde da Família: atividade de integração ensino-serviço na enfermagem. Rev Gaúcha Enferm. 2010;31(1):183-6.

12. Pereira WR, Chaouchar SH. Identificação de novas práticas pedagógicas na percepção dos docentes de um curso de enfermagem. Ciênc Cuid Saúde. 2010;9(1):99-106.

13. Johnson IL, Scott FE, Byrne NP, MacRury KA, Rosenfild J. Integration of community health teaching in the undergraduate medicine curriculum at the University of Toronto. Am J Prev Med. 2011;41(4 Suppl 3):176-80.

14. Silva RPG, Rodrigues RM. Sistema Único de Saúde e a graduação em enfermagem no Paraná. Rev Bras Enferm. 2010;63(1):66-72.

15. Marques CMS, Egry EY. The competencies of health professionals and the ministerial policies. Rev Esc Enferm USP [Internet]. 2011 [cited 2012 Nov 05];45(1):187-93. Available from: http://www.scielo.br/pdf/reeusp/v45n1/en_26.pdf

16. Gil CRR, Turini B, Cabrera MAS, Kohatsu M, Orquiza SMC. Interação ensino, serviços e comunidade: desafios e perspectivas de uma experiência de ensino-aprendizagem na atenção básica. Rev Bras Educ Med. 2008;32(2):230-9.
17. Medeiros VC, Peres AM. Atividades de formação do enfermeiro no âmbito da Atenção Básica à Saúde. Texto Contexto Enferm. 2011;20(n. esp):27-35.

18. Pizzinato A, Gustavo AS, Santos BRL, Ojeda BS, Ferreira E, Thiesen FV, et al. A integração ensino-serviço como estratégia na formação profissional para o SUS. Rev Bras Educ Med. 2012;36(1 Supl 2):170-7.

19. Finkler M, Caetano JC, Ramos FRS. Integração "ensinoserviço" no processo de mudança na formação profissional em Odontologia. Interface Comunic Saúde Educ. 2011;15(39):1053-67.

20. Abarca CR, Bolton RM. Enseñanza centrada en el estudiante. Rev Estudios Med Human [Internet]. 2007 [citado 2012 nov. 05];15(15). Disponible en: http://escuela.med.puc.cl/publ/ arsmedica/ArsMedica15/EnsenanzaCentrada.html

21. Scherer ZAP, Scherer EA, Carvalho AMP. Reflexões sobre o ensino da enfermagem e os primeiros contatos do aluno com a profissão. Rev Latino Am Enferm. 2006;14(2): 285-91.

22. Stella RCR, Abdala IG, Lampert JB, Perim GL, Aguilar-da-Silva RH, Costa NMSC. Cenários de prática e a formação médica na assistência em saúde. Rev Bras Educ Med. 2009;33 Supl 1:63-9.

23. Backes DS, Grando MK, Gracioli MSA, Pereira AD, Colomé JS, Gehlen MH. Vivência teórico-prática inovadora no ensino de enfermagem. Esc Anna Nery Rev Enferm. 2012;16(3):597-602.

24. Semim GM, Souza MCBM, Corrêa AK. Professor como facilitador do processo ensino-aprendizagem: visão de estudante de enfermagem. Rev Gaúcha Enferm. 2009; 30(3):484-91

25. Ferreira RC, Fiorini VML, Crivelaro E. Formação profissional no SUS: o papel da Atenção Básica em Saúde na perspectiva docente. Rev Bras Educ Med. 2010;34(2): 207-15.

26. Bettancourt L, Muñoz LA, Merighi MAB, Santos MF. Nursing teachers in clinical training areas: a phenomenological focus. Rev Latino Am Enferm. 2011;19(5):1197-204.

27. Mourão LC, L'Abbate S. Implicações docentes nas transformações curriculares da área da saúde: uma análise sóciohistórica. Online Braz J Nurs [Internet]. 2011 [citado 2012 nov. 05];10(3). Disponível em: http://www.objnursing.uff. br/index.php/nursing/article/view/3423
Correspondence addressed to: Laura Cavalcanti de Farias Brehmer Av. Mauro Ramos, 278, Apto. 1005, Centro CEP 88020-300 - Florianópolis, SC, Brazil 